\title{
The Effect of Book-Tax Conformity, Investment Opportunity Set, and Audit Quality on Earnings Response Coefficient
}

\author{
Sasya Sabrina*, Chandra Wijaya, Edwin Hendra \\ Accounting Department, Faculty of Economics and Communication, Bina Nusantara University, Jakarta, Indonesia 11480 \\ *sasyasabrina@binus.ac.id,sasyasabrina@gmail.com
}

\begin{abstract}
The purpose of this study is to determine the impact of book-tax conformity, investment opportunity set, and audit quality to earnings response coefficient. This research is conducted on Indonesian manufacturing company listed in Indonesia Stock Exchange 2016-2018. The data of this research are obtained from the financial statements of the companies and analyzed using multiple linear regression method. The results of this study concluded that book-tax conformity, investment opportunity set, and audit quality have significant impact on earnings response coefficient. These results indicate that investor has consider the conformity between income tax and accounting report, market as well as book value of a company assets, and the quality of an audit that the company proceed.
\end{abstract}

Keywords: Book, Tax Conformity, Audit Quality

\section{INTRODUCTION}

Financial reports are records of a company's financial information in an accounting period that can be used to describe the company's performance. Users of financial statements are people who have an interest in using these financial reports, both external and internal to the entity. Internal parties of the entity, such as directors, managers, employees, and others are responsible for financial reports, they use financial reports as a benchmark for evaluating company performance and making economic decisions. Meanwhile, external parties such as the government, creditors, and investors conduct analysis on the performance of financial statements with the aim of economic / business decisions.

However, even though management knows that financial statements are used for the public interest, management often changes the numbers in the financial statements for certain purposes. This action can be done under compulsion or voluntary for the interests of the company, personal, or both. For investors, net income is one of the benchmarks for investors to assess how well the company is developing. Net income is the element that gets the most attention for external parties. Thus, management can take advantage of this to carry out earnings management practices. Earnings management practices carried out by management caused by the separation of interests between the principal (shareholder) and the agent (management). This is known as agency conflict.

Agency conflicts can result in management manipulating financial reports by optimizing profits for certain interests. Thus, the reported earnings are not in their true condition. Management actions that carry out earnings management can cause various responses from external parties, especially investors. The stronger the reaction given by the market to earnings information, it can be said that the reported profit is of quality, the weaker the reaction given by the market to the earnings information, it can be said that the reported profit is not of quality. The strong market reaction to earnings information reported by companies is reflected in the high earnings response coefficient (ERC), which indicates quality earnings.

Of course, there are lots of incentives that can encourage management to carry out earnings management, one of which is for tax purposes. Management tends to reduce the value of reported earnings so that the tax reported by the company is low. Taxes are essential for countries and companies. The state and companies have their own interests related to taxes. For the state, taxes are the main income for economic growth, while for companies, taxes are a deduction from reported net income. Various studies related to earnings management and tax management have been carried out and have shown a positive correlation between the two, for example, research conducted by [1]. This study shows the results that the goal of earnings management is to reduce the amount of tax that must be paid. The higher the difference between accounting profit and taxable profit, it shows that there is an aggressive earnings management practice in the company. 
Book-tax conformity is the degree of flexibility of a company to present different accounting income from taxable income. High book-tax conformity can generate positive and negative signals for investors. The higher the company's book-tax conformity as a positive signal for investors, it can hinder managers from reporting accounting and fiscal earnings aggressively [2]. This is in line with research conducted by [3] which states that when management optimizes the amount of tax burden paid by the company, investors will respond positively as evidenced by an increase in the company's share price. However, the higher the company's book-tax conformity can also give a negative signal, namely the loss of information on the capital market as a result of the increase in booktax conformity [2]. This opinion is also supported by research conducted by [4] which states that the quality of company earnings is lowered by the existence of book-tax conformity. Thus, all stakeholders, especially investors, will reduce their level of confidence in the information in the financial statements if the company has a high booktax conformity. A high book-tax conformity can lead to a reduced level of informativeness from earnings, as the element that gets the most attention from investors and as important information in financial statements, which can be measured using the proxy earnings response coefficient (ERC).

[5] argue about the signaling theory that if the company's performance is good, managers will provide signals related to the company's performance to investors, stakeholders and the market by conducting disclosures. The information contained can trigger market reactions, especially investors if they provide important information such as those related to stock prices. The information provided to investors will make investors think whether the related company can grow in the future by generating a high enough return. Of course, in this case investors will see the company's opportunities to grow (investment opportunity set). According to [6], company value is influenced by two things, namely assets currently held (assets in place) and options to invest in the future. The investment opportunity set focuses more on investment options in the future, which means that the value of the company depends on the expenditures determined by management in the future, in the form of investment options that are expected to produce greater returns.

With the increase in the investment opportunity set, the actions of the agent (management) become unobservable, which can cause the principal (shareholder) to be unable to predict decisions from management and not knowing that what management is doing is what the management wants. principal or not. Thus, the high investment opportunity set tends to cause management to carry out earnings management practices which can make earnings quality decline. Decreasing earnings quality will make the information presented by the company less informative, so that it will have an impact on the earnings response coefficient (ERC).

Furthermore, [7] stated that the information contained in financial reports can be defined as changes in expectations and behavior of investors in making investment decisions. Financial reports are said to have high credibility if they have high audit quality. Audit quality has a significant role in maintaining the standards and performance of the company's operations. Audit quality is becoming increasingly important in line with the case that occurred at Enron which was caused by a lack of good quality audit facilities. Based on the explanation above, the purpose of this study is to find out and analyze whether book-tax conformity, investment opportunity set, and audit quality can positively or negatively affect the earnings response coefficient in manufacturing industrial companies during the 3 years period, in 2016- 2018.

\section{LITERATURE REVIEW HYPOTHESIS DEVELOPMENT}

\subsection{Signaling Theory}

Signal theory suggests how companies provide signals to stakeholders. Signal theory shows the existence of information asymmetry between company management and the parties with an interest in the information. For this reason, management needs to provide information to interested parties through the publication of financial reports. Signal theory suggests how a company should provide signals to users of financial statements. The signal in question is information related to company performance that can reflect the company's future prospects [8]. Signal theory reflects the qualities inherent in the elements of each signal that make the signal convincing and attractive. The signal provided by the company is the information contained in the financial statements. The information contained in financial statements allows users of financial statements to see the company's current condition and predictions in the future. Of course, the information presented will be an important consideration in stakeholder decision making. 


\subsection{Book-Tax Conformity}

The difference between accounting profit and taxable profit grew substantially in the 1990s based on estimates made by several government agencies and researchers. The reasons that exist related to this problem are not known with certainty, many argue that the opportunistic measurement of accounting profit and taxable profit has been reported by management so that differences arise. The problem between the difference in accounting profit and taxable profit is not because they are different, but the problem here is that these differences can be affected by misleading activities, manipulation in the company in reporting accounting profit, taxable profit, or both. Previous studies have found variations on book-tax conformity seen from various countries. This study results in a report that the level of earnings information is lower in countries with a high level of book-tax conformity than in countries with a low level of book-tax conformity. After several years, a new understanding of book-tax conformity emerged, [9] defines book-tax conformity as the degree of flexibility of a company to present different accounting earnings from taxable income. Book-tax conformity is the extent to which accounting profit and taxable profit are the same because both numbers are calculated using the same measurement and recognition practices.

\subsection{Investment Opportunity Set}

The investment opportunity set (IOS) is a combination of investment decisions between assets in place and positive net present value (NPV) that will affect firm value. The option to invest is influenced by the manager's future expenditure, while assets in place do not require investment. According to [10], IOS are expenditures determined by management in the future as company value. This expenditure is the investment options in order to obtain a large return. Several proxies have been used for the investment opportunity set, classified into three types: price-based proxies, investment-based proxies, and variance measures [11]. Price-based proxies are divided into: book to market value of assets, MVA / BVA [12]; Tobin's Q [13]; earnings to price ratios, E / $\mathrm{P}$ [12]; ratio of property, plant, and equipment to firm value, PPE / V [13]; and the ratio of depreciation to firm value, DEP / V [12]. This IOS proxy is based on the idea that the company's growth prospects are partially incorporated in the stock price, and the company's growth has a greater market value than assets in place. Investment-based proxies are divided into: the ratio of R\&D to assets, R \& D / A [10]; sales, R \& D / S [13]; and firm values, R \& $\mathrm{D} / \mathrm{V}[12]$; and the ratio of capital expenditures to value, CAPX / V [12]. This IOS proxy is based on the idea that a company's high investment level has a positive effect on the investment opportunity set of the company. Variance measures are divided into: the variance of returns [10] [12], and asset betas [13]. This proxy reveals that an option will be more valuable if it uses size variability to estimate the size of the growing option, such as the variability of return that underlies the increase in assets [14].

\subsection{Audit Quality}

Audit quality is a variable whose measurement is still debatable. There have been many studies to conceptualize audit quality in the past. However, there is no result that can achieve universal recognition in terms of the definition of audit quality itself. [15] states that audit quality is the market's assessment of the auditor on how the auditor finds violations in the client's accounting system and reports the violation. This definition will address two important aspects of audit quality. First, that the competence of the public accounting firm is assessed by how often the public accounting firm detects misstatements. Second, the independence and objectivity of the auditor, which concerns how the auditor responds to the misstatements that have been detected.

\subsection{Earnings Response Coefficient}

Earnings response coefficient (ERC) as a measure of the abnormal return of a financial instrument as a response to changes in unexpected earnings issued by the company that owns the instrument. Meanwhile, [16] stated that ERC reflects a reaction that reflects the quality of earnings announced by the company. Basically, it is believed that ERC can be used to believe in the quality of earnings in financial reports because it shows how useful earnings information is for investors' decision making. The small ERC value indicates that the information contained in the company's profit figures stated in the financial statements is less informative and useful for investors in making decisions. Conversely, a high ERC value indicates that earnings information is useful for investor decision making.

\subsection{Book-Tax Conformity and ERC}

High book-tax conformity can indicate aggressive tax avoidance efforts, through earnings management practices, which will lead to low earnings quality. For example, research conducted by [9] conducted a study on the effect of book-tax conformity on earnings quality, as measured by earnings persistence, which shows the negative effect of book-tax conformity on earnings quality. [1] also 
conducted a study which states that the level of earnings management activities will increase along with the increase in book-tax conformity. The increase in book-tax conformity can cause changes in managers' goals in using accounting policies. The manager's policy, which was originally intended to provide information about the company's performance to stakeholders, can be misused, for example, to minimize taxes that must be paid. This can happen if the accounting standards are changed to comply with tax regulations or vice versa. Because there is an incentive from management to reduce tax burden, managers can be more aggressive in estimating and recording potential future losses, which will lead to a decline in the quality of earnings information. Thus, book-tax conformity is believed to have a negative effect on earnings response coefficient.

Ha1: The level of book-tax conformity has a negative effect on earnings response coefficient in Indonesia. 2.7. Investment Opportunity Set and ERC [13] states that companies with higher investment opportunities show greater earnings management. Large earnings management practices can cause the quality of earnings to decline, so that it will affect the level of reported earnings information. According to [17], managers of high growth companies use earnings management more to mark their information about the company's future growth opportunities. In addition, [18] state that when a company has a high IOS, the company value will increase because more investors are interested in investing with the hope of getting a greater return in the future, causing the possibility of company management to do management profit due to maintain company growth.

This opinion is reinforced by the statement of [19] which states that companies with high IOS allow management to carry out earnings management to maintain company growth, which in turn can reduce the quality of reported earnings. The decline in the quality of reported earnings will cause the level of earnings informativeness to decrease. [20] also state that the unobservable actions of management cause the principal not to know that the actions of management are in accordance with the principal's wishes or not, which causes management to freely manage earnings.

Ha2: The level of investment opportunity set has a negative effect on earnings response coefficient in Indonesia.

\subsection{Audit Quality and ERC}

Financial reports are said to have high credibility if they have high audit quality. High audit quality increases earnings quality and earnings informativeness. Thus, audit quality is believed to strengthen investor confidence in the information in financial reports, especially earnings information. Furthermore, research conducted by [21] shows that audit quality which is proxied by using restatements (restatement of financial statements) has a significant positive effect on earnings persistence which is a proxy for a company's earnings quality. When earnings persistence, which is a proxy for earnings quality, increases, investor confidence in earnings informativeness will increase, so that it will have an impact on the company's earnings response coefficient. Companies that perform restatements are believed to have higher audit quality than companies that do not make restatements, which will have an impact on increasing the company's performance and earnings response coefficient.

Ha3: The level of audit quality has a positive effect on earnings response coefficient in Indonesia.

\section{MATERIAL AND METHODS}

The data analysis method used in this research is multiple linear regression analysis. This study uses secondary data from financial statements of Indonesian manufacturing companies listed in Indonesia Stock Exchange in 2016-2018. The samples are the companies that have positive tax profits and do not change their fiscal year from 20162018. From this criteria, 77 manufacturing companies listed on the Indonesia Stock Exchange were possible to be selected as samples. With an error rate of $5 \%$ and the outlier data screening process based on z-scores and boxplots, the number of samples selected in this study with a 3-year study period from 2016-2018 was 132 panel data samples from 44 companies.

The independent variable is a variable that affects the dependent variable either positively or negatively. In accordance with the regression model described above, the following is an explanation of the four elements of the independent variables used in this study:

- Book-Tax Conformity. In this study, the measurement of the book-tax conformity level will follow the measurement model used in [9], which is based on the root mean-squared error (RMSE) of the current tax expense (CTE) regression on pre-tax book income (PTBI) and dividends (Div). The current tax expense is regressed against pre-tax book income and dividends, each of which has been divided by total assets, to obtain the standard error of estimate from the regression, which is then 
equivalent to RMSE. Then, it is the descending rank of RMSE that becomes the book-tax conformity value. The largest RMSE will be ranked 0 , and the smallest RMSE will be ranked $\mathrm{n}-1$, then each ranking will be divided by $\mathrm{n}-1$ to scale the range from 0 to 1 . This study regresses CTE against PTBI and dividends per sector per year, to obtain the book-tax conformity value for each sector in a certain year, which is then generalized to all companies in that sector. So, every company in the same sector, in the same year, will have the same book-tax conformity.

- Investment Opportunity Set. IOS is measured using a price-based proxy, namely by calculating the market value of assets to book value of assets (MVA BVA). Price-based proxies can show the comparison of market value to real assets [11].

- Audit Quality is audit quality that is measured by using indicators of restatement of financial statements. In this study, restatement is a dummy variable, where if there is a restatement it is given a value of 1 , while if there is no restatement it is given a value of 0 .

For the dependent variable, the steps for calculating ERC are based on research conducted by [22]. It measures earnings response coefficient by using the slope coefficient from the regression of cumulative abnormal return $(\mathrm{CARi}, \mathrm{t})$ on unexpected earnings $(\mathrm{UEi}, \mathrm{t})$. So that the regression model used in this study is as follows:

$\mathrm{CAR}_{\mathrm{i}, \mathrm{t}}=\alpha_{0}$ year $+\alpha 1 \mathrm{BTaxC}_{\mathrm{t}}+\alpha 2 \mathrm{IOS}_{\mathrm{i}, \mathrm{t}}+\alpha 3 \mathrm{AQ}_{\mathrm{i}, \mathrm{t}}$ $+\alpha 4 \mathrm{UE}_{\mathrm{i}, \mathrm{t}} \times \mathrm{BTaxC}_{\mathrm{t}}+\alpha 5 \mathrm{UE}_{\mathrm{i}, \mathrm{t}} \times \mathrm{IOS}_{\mathrm{i}, \mathrm{t}}+\alpha 6 \mathrm{UE}_{\mathrm{i}, \mathrm{t}} \mathrm{x}$ $\mathrm{AQ}_{\mathrm{i}, \mathrm{t}}+\varepsilon_{\mathrm{i}, \mathrm{t}}$

Explanation:

$\begin{array}{ll}\text { CAR } & =\text { Cumulative Abnormal Return } \\ \text { UE } & =\text { Unexpected Earnings } \\ \text { BTaxC } & =\text { Tingkat book-tax conformity } \\ \text { AQ } & =\text { Audit Quality (Kualitas Audit) } \\ \text { IOS } & =\text { Investment opportunity set } \\ \varepsilon & =\text { Error }\end{array}$

The coefficients used in this model are $\mathrm{UE}_{\mathrm{i}, \mathrm{t}} \mathrm{X}$ $\mathrm{BTaxC}_{\mathrm{t}}, \mathrm{UE}_{\mathrm{i}, \mathrm{t}} \times \operatorname{IOS}_{\mathrm{i}, \mathrm{t}}$, and $\mathrm{UE}_{\mathrm{i}, \mathrm{t}} \mathrm{x} \mathrm{AQ}_{\mathrm{i}, \mathrm{t}}$ which show the effect of each variable on the earnings response coefficient.

\section{RESULTS AND DISCUSSION}

The following are the results of the $t$ test on the regression model:

TABLE 1. t-test

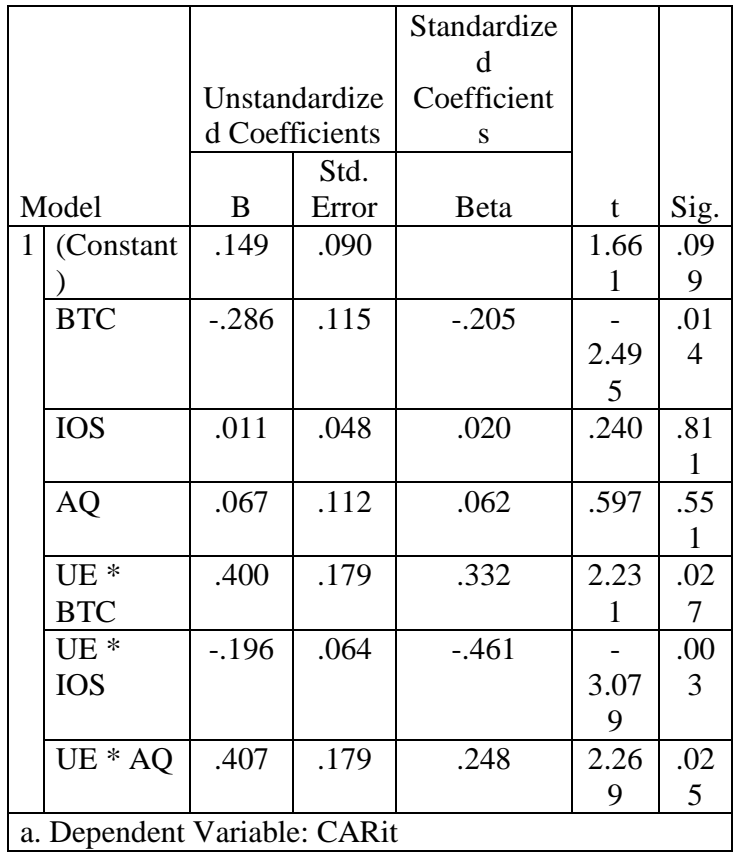

Based on the results of the t-test statistics above, several discussions can be obtained as follows:

- The book-tax conformity level has a positive effect on the earnings response coefficient. This means that the less the difference between accounting profit and taxable profit, the higher the earnings quality in the financial statements, which indicates how useful earnings information is for investors' decision making. When the book-tax conformity level is high, management will tend to report earnings figures truthfully. The analysis is when management reports the profit rate is too high, the consequences that must be faced are owner satisfaction and increased tax burden. Meanwhile, when management reports the profit rate is too low to understate the amount of tax paid, it can result in owner dissatisfaction with management performance. So, the middle way that management can choose is to report profits in truth and pay the tax burden in the appropriate amount. Management can explain to the owner that the figures shown are real results of performance and that the tax expense paid is indeed a liability that must be paid. Thus, in conditions where a high level of conformity between accounting profit and taxable profit is required, management will report real and true 
profit figures, so that it becomes a fairly accurate benchmark to reflect profit information that is useful for investor decision making.

- The level of investment opportunity set has a negative effect on earnings response coefficient. This means, the decreasing opportunities for the company to invest which are expected to result in a greater return for the company, the higher the quality of earnings in the financial statements which shows how useful earnings information is for decision making by investors. When management within the company tries to make expenses so that the company grows, the investment opportunities management will make uncertain decisions and of course will make management's actions unobservable. When management's actions are carried out unobservable, it will result in the information being not transparent and not known to investors. Thus, because investors do not know the actions taken by management according to their wishes, earnings informativeness will decrease. When a company has a high IOS value, it will raise expectations to investors that the company will have prospects for future profits. Investors' expectations for the company are that the company will generate greater returns in the future. This expectation can cause the company to carry out earnings management in order to maintain the company's growth so that it is able to meet the expectations of its investors or shareholders.

- The level of audit quality has a positive effect on earnings response coefficient. This means, if the company performs a restatement, the higher the quality of earnings in the financial statements, which shows how useful earnings information is for decision making by investors. When a company restates its financial statements, it is believed that the quality of earnings will improve due to the company's previously published financial statements being corrected for errors. When doing a restatement, investors must know that the ability to use one period's earnings as a benchmark to predict future earnings before restatement can be different after restatement in that year. It is this difference that can have a significant effect on the estimated valuation and future investment decisions. Overall, restatement has a significant impact on the predictive power of earnings and increases in disclosures and transparency. With the increase in disclosures and transparency, of course, the earnings information presented to investors will increase.

\section{CONCLUSION}

- Book-tax conformity (BTC) has a positive effect on earnings response coefficient (ERC). This shows that manufacturing industry investors in Indonesia pay attention to the level of flexibility of companies in reporting taxable income that is different from accounting profit and indirectly also indicates that investors are concerned with the amount of tax paid by companies.

- Investment opportunity set (IOS) has a negative effect on earnings response coefficient (ERC). This shows that investors in Indonesia consider how much a company can grow with different market value and book value of assets.

- Audit quality (AQ) has a positive effect on earnings response coefficient (ERC). This shows that audit quality is also a factor considered by investors as a determinant of earnings information, as indicated by the quality of earnings in making decisions.

\section{REFERENCES}

[1] B. Blaylock, F. Gaertner and T. Shevlin, "The association between book-tax conformity and earnings management," Review of accounting studies, vol. 20, no. 1, pp. 141-172, 2015.

[2] T. Y. Tang, "Does book-tax conformity deter opportunistic book and tax reporting? An international analysis," European Accounting Review, vol. 24, no. 3, pp. 441-469, 2015.

[3] K. Blaufus, A. Mohlmann and A. N. Schwabe, "Stock Price Reactions To News About Corporate Tax Avoidance And Evasion," Journal of Economic Psychology, vol. 72, pp. 278-292, 2019.

[4] N. A. Rachmawati, "Book-Tax Conformity dan Kualitas Laba," Jurnal Riset dan Aplikasi: Akuntansi dan Manajemen, vol. 1, no. 3, p. 192 -201, 2016.

[5] K. A. Yimenu and S. A. Surur, "Earning Management: From Agency and Signalling Theory Perspective in Ethiopia," Journal of Economics, Management and Trade, pp. 1-12, 2019.

[6] N. S. Nurhayati, "The Influence of Profitability, Liquidity, and Investment Opportunity to Dividend Policy on Companies Listed in the LQ-45 Index," in 1st International Conference on Economics, Business, Entrepreneurship, and Finance (ICEBEF 2018), 2019. 
[7] X. Hu, J. Tang and Q. Wang, "Revisions about Government Subsidy Disclosures and Investors Response to Earnings Reports: Evidence from the 2017 Government Subsidy Disclosures," Applied Finance and Accounting, vol. 5, no. 2, pp. 26-34, 2019.

[8] B. L. Connelly, S. Certo, R. D. Ireland and C. R. Reutzel, "Signaling theory: A review and assessment," Journal of Management, vol. 37, no. 1, pp. 39-67, 2011.

[9] T. J. Atwood, S. D. Michael and A. M. Linda, "Book-Tax Conformity, Earnings Persistence And The Association Between Earnings And Future Cash Flows," Journal of Accounting and Economics, vol. 50, no. 1, pp. 111-125, 2010.

[10] J. J. Gaver and K. M. Gaver, "Additional evidence on the association between the investment opportunity set and corporate financing, dividend, and compensation policies," Journal of Accounting and Economics, vol. 16, no. 1-3, pp. 125-160, 1993.

[11] S. Kallapur and M. A. Trombley, "The Association Between Investment Opportunity Set Proxies and Realized Growth," Journal of Business Finance \& Accounting, vol. 26, no. 3-4, pp. 505-519, 1999.

[12] C. W. Smith and R. L. Watts, "The investment opportunity set and corporate financing, dividend, and compensation policies," Journal of Financial Economics, vol. 32, no. 3, pp. 263-292, 1992

[13] D. J. Skinner, "The investment opportunity set and accounting procedure choice: Preliminary evidence," Journal of Accounting and Economics, vol. 16, no. 4, pp. 407-445, 1993.

[14] N. Hidayah, "Pengaruh Investment Opportunity Set (IOS) Dan Kepemilikan Manajerial Terhadap Nilai Perusahaan Pada Perusahaan Property Dan Real Estate Di Bursa Efek Indonesia," Jurnal Akuntansi, vol. 19, no. 3, pp. 420-432, 2015.

[15] L. E. DeAngelo, "Auditor size and audit quality," Journal of accounting and economics, vol. 3, no. 3, pp. 183-199, 1981.

[16] M. Mahjoubi and E. Abaoub, "Earnings Response Coefficient As A Measure Of Market Expectations: Evidence From Tunis Stock Exchange," International Journal of
Economics and Financial, vol. 5, no. 2, pp 377-389, 2015.

[17] F. A. Gul, S. Leung and B. Srinidhi, "Informative and Opportunistic Earnings Management and the Value Relevance of Earnings: Some Evidence on the Role of IOS," SSRN Electronic Journal, 2003.

[18] K. A. A. Jaya and D. G. Wirama, "Pengaruh Investment Opportunity Set, Likuiditas, dan Ukuran Perusahaan Pada Kualitas Laba," EJurnal Akuntansi Universitas Udayana, vol. 21, no. 3, pp. 2195-2221, 2017.

[19] R. Rosmaryam and Z. Zainuddin, "Investment Opportunity Set (IOS) dan Pengaruhnya terhadap Kualitas Laba (Studi pada Perusahaan LQ-45 yang Terdaftar di Bursa Efek Indonesia)," Future: Jurnal Manajemen dan Akuntansi, vol. 4, no. 1, pp. 120-141, 2016.

[20] N. Putra and S. Subowo, "The Effect of Accounting Conservatism, Investment Opportunity Set, Leverage, and Company Size on Earnings Quality," Accounting Analysis Journal, vol. 5, no. 4, pp. 299-306, 2016

[21] G. A. Ndubizu and M. Sallehu, "Do Restatements Improve the Persistence of Earnings and Its Components?," Accounting Perspectives, vol. 16, no. 4, pp. 371-427, 2017.

[22] A. O. Okolie, "Audit Quality and Earnings Response Coefficients of Quoted Companies in Nigeria," Journal of Applied Finance \& Banking, vol. 4, no. 2, pp. 1-10, 2014. 